\title{
Clonality Analysis of Giant Cell Lesions of the Jaws
}

\author{
Fabrício Rezende AMARAL ${ }^{1}$ \\ Carolina Cavaliéri GOMES ${ }^{1}$ \\ Carla Silveira OLIVEIRA ${ }^{1}$ \\ Paulo Eduardo Alencar de SOUZA ${ }^{2}$ \\ Ricardo Santiago GOMEZ ${ }^{1}$ \\ ${ }^{1}$ Department of Oral Surgery and Pathology, Dental School, \\ Federal University of Minas Gerais, Belo Horizonte, MG, Brazil \\ ${ }^{2}$ Dental School, Pontifical University Catholic of Minas Gerais, Belo Horizonte, MG, Brazil
}

\begin{abstract}
Despite the importance of clonality to understand the pathogenesis and progression of tumors, it has not been investigated yet in giant cell lesions of the jaws. The aim of this study was to analyze the clonality of peripheral giant cell lesions (PGCL) and central giant cell lesions (CGCL) of the jaws. Six samples of PGCL and 5 samples of CGCL were analyzed in this study using the polymorphic human androgen receptor locus (HUMARA) assay. Three out of the 5 samples of the CGCL and 3 out of 6 samples of PGCL exhibited a monoclonal pattern. Our findings demonstrate that some giant cell lesions of the jaws are clonal, which indicate that these lesions may have a common genetic mechanism of development. Further studies are necessary to better elucidate the molecular mechanisms involved in the pathogenesis of such lesions.
\end{abstract}

Key Words: clonality, clonal nature, giant cell lesion, giant cell granuloma, HUMARA.

\section{INTRODUCTION}

Central giant cell lesion (CGCL) is an intraosseous lesion of unknown etiology that occurs mainly in the mandible of patients ranging from 10 to 25 years (1). Radiographic findings are diverse, ranging from small unilocular lesions to large multilocular lesions with displacement of teeth, root resorption, and cortical perforation (2). Peripheral giant cell lesion (PGCL) is a reactive lesion usually related to local irritating factors in gingival (3). Histologically, PGCL and CGCL are characterized by the presence of multinucleated osteoclast-like giant cells in a background of oval to spindle-shaped mononuclear cells (4).

The study of clonal origin of tumors can help to elucidate the pathogenesis and progression of the diseases. A clonal population of cells is by definition cells arising from mitotic division from a single somatic cell (5). The cells constituting a single clone are not necessarily genetically identical, because clonal evolution may occur within such populations of cells
(6). For detection of clonal populations that do not have known genetic markers, detection of clonality by phenotypic assays is necessary (7).

The most frequently used phenotypic clonality technique is based on the X-chromosome inactivation principle. In females, during early embryonic development, there is inactivation of one $\mathrm{X}$ and it is passed to the progeny of the cell in a stable manner (8). Females heterozygous for polymorphic $\mathrm{X}$-chromosome inactivation are therefore mosaics regarding X-chromosome activity (9). There is evidence that X-chromosome inactivation is related to differential methylation of cytosine in the DNA of X-chromosome genes (10). Determination of maternal and paternal X chromosome activation status is useful in the diagnostic analysis of nonrandom $\mathrm{X}$ inactivation patterns and it has been of interest in studies of clonality of neoplastic cells in females (11).

The human androgen receptor (HUMARA) gene polymorphism assay is the most used method to distinguish the active and inactive $\mathrm{X}$ chromosome.

Correspondence: Dr. Fabrício Rezende Amaral, Departamento de Cirurgia Oral e Patologia, Faculdade de Odontologia, Universidade Federal de Minas Gerais, Avenida Antônio Carlos, 6627, 31270-901 Belo Horizonte, MG, Brasil. Tel: +55-31-3409-2477. Fax: +55-31-3409-2430. e-mail: fabricioramaral@superig.com.br 
The HUMARA gene presents an in-frame CAG trimeric repeat encoding 11-31 glycine residues in the first exon. This repeat is highly polymorphic, with a heterozygosity of $90 \%$. The HUMARA assay is based on this high heterozygosity. It consists in the use of a methylation-sensitive enzyme followed by polymerase chain reaction amplification. If the sites of restriction are unmethylated, digestion will occur between the flanking oligonucleotides and the following amplification will not be possible.

On the other hand, if the restriction sites are methylated, no digestion will occur and the primers will produce a proper amplification of the target sequence in the PCR (12). In other words, as each female cell has one inactive $\mathrm{X}$-chromosome, the amplification of 2 different size fragments in the PCR indicates cells from different clonal origin. The amplification of the target DNA without the enzymatic digestion is essential to eliminate the females that show homozygosity, as they are not informative (12). The HUMARA method is more widely applicable than protein isoforms and transcription-based methods because the variable number of CAG nucleotides repeat allows most patients to be informative for the assay (12).

Although there are few studies that investigated the clonal nature of the giant cell tumor of the bone (13), as far as we could ascertain, there are no published data regarding clonality of giant cell lesions of the jaws. Therefore, the objective of this study is to investigate the clonal nature of PGCL and CGCL of the jaws using the polymorphic human androgen receptor locus (HUMARA) assay.

\section{MATERIAL AND METHODS}

\section{Tissue and DNA Extraction}

A total of 6 samples of PGCL and 5 samples of CGCL were included in this study. All the subjects were female. The project was approved by the local ethics committee and an informed consent was obtained from each patient. The CGCL was considered aggressive when the lesion was larger than $4 \mathrm{~cm}$ in size, and the cortical bone was damaged or expanded and teeth displaced. In each case, a portion of the lesion was resected, immediately snap frozen and stored at $-80^{\circ} \mathrm{C}$. For diagnosis confirmation, a portion of the tissue was fixed in $10 \%$ buffered formalin and paraffin embedded. The DNA extraction from the fresh tissue was carried out as previously described (14).

\section{Digestion}

One microgram of DNA was digested by 5.0 units of HhaI (New England Biolabs, Ipswich, MA, USA). The digestion conditions were: $37^{\circ} \mathrm{C}$ for $1 \mathrm{~h}$ followed by $65^{\circ} \mathrm{C}$ for $20 \mathrm{~min}$ for the enzyme inactivation. In each time, the same amount of DNA of all samples was incubated with the enzyme digestion buffer and without the enzyme. In each reaction, a positive control was included to assure that the reaction occurred properly.

\section{Polymerase Chain Reaction (PCR)}

For each sample 100 ng ofDNA template digested with the enzyme and $100 \mathrm{ng}$ incubated without the enzyme were used separately in a PCR reaction. PCR was performed using primers previously described (12). The $25 \mu \mathrm{L}$ of PCR mixture included $2.5 \mu \mathrm{L}$ of each DNTP $(100 \mu \mathrm{M}), 2.5 \mu \mathrm{L}$ of $10 \times$ PCR buffer (Invitrogen, São Paulo, SP, Brazil), $0.8 \mu \mathrm{L}$ of $50 \mathrm{mM} \mathrm{MgCl}_{2}$,(Invitrogen), 10 pmol of each primer (XXIDT, Coralville, IA, USA), and $0.5 \mu \mathrm{L}$ of Taq platinum (Invitrogen). Briefly, PCR conditions included an initial denaturing step at $95^{\circ} \mathrm{C}$ for $8 \mathrm{~min}$, followed by 34 amplification cycles of $95^{\circ} \mathrm{C}$ for $40 \mathrm{~s}, 58^{\circ} \mathrm{C}$ for $45 \mathrm{~s}$ and $72^{\circ} \mathrm{C}$ for $45 \mathrm{~s}$. Final extension consisted of $72^{\circ} \mathrm{C}$ for $10 \mathrm{~min}$.

PCR amplification was analyzed in an $8 \%$ polyacrylamide gel. Two individuals analyzed the results separately. The relative density of the 2 alleles in the digested samples was compared visually with those of the non-digested samples. Monoclonal cases were considered as those in which one of the alleles showed a complete loss or a significantly diminished density compared with its density in the non-digested counterpart. On the other hand, when the relative density of both alleles did not change significantly, the lesion was considered polyclonal.

\section{RESULTS}

The gel electrophoresis showing amplification of the human androgen receptor gene (HUMARA) with and without HhaI digestion is shown in Figure 1. Most of the giant cell lesions investigated presented a monoclonal pattern ( 6 out of 11 cases).

Three out of 6 PGCL and 3 out of 5 CGCL exhibited a monoclonal pattern (Table 1). No association 
was observed between clonality and aggressiveness of the lesion.

\section{DISCUSSION}

It is widely known that most tumors have a monoclonal composition consistent with the somatic mutation theory of carcinogenesis, which postulates that a tumor results from the progeny of a single cell having acquired one or more somatic mutations (15). Studies involving the clonal nature of lesions are very important, because clonality and mutation studies may help to create phylogenetic trees and gatekeeper mutations can be identified (16).

Despite all the evidence of a clonal nature of most tumors, tumorigenesis is considered a dynamic spectrum of progression in genetic abnormalities and growth advantages. An important aspect to be considered in clonal mutation is at what stage in the life-history of the tumor it is examined (17). It may progress from an early polyclonal reactive stage into a monoclonal expansion. A tumor may be originated from several cells, the progeny of one of these cells eventually out-grow all the others $(6,18)$. Another caveat relevant in clonal analysis is the size of clonal field in normal tissues. A larger clonal field in normal tissue has more implications in claiming that a process arriving at this tissue is clonal (17).

In the present study, 6 out of 11 samples of PGCL and CGCL were monoclonal, indicating that some giant cell lesions originate from one clone of altered cells. These data may initially suggest that these lesions have a neoplastic nature. However, the definition of a benign neoplasia is a more complex issue. Although reactive lesions are usually polyclonal and neoplastic lesions are
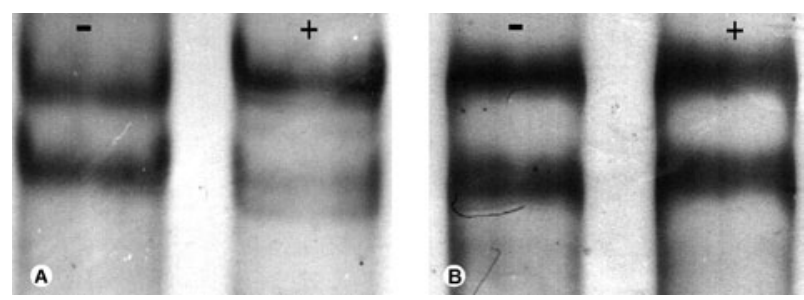

Figure 1. Gel electrophoresis showing amplification of the human androgen receptor gene (HUMARA). A: Amplification without (-) and with $(+)$ the HhaI digestion. It can be observed a significant loss of the short allele, representing a monoclonal pattern. B: Amplification without (-) and with (+) the HhaI digestion. It can be observed amplification of 2 alleles representing a polyclonal pattern. monoclonal, there are examples of monoclonal reactive or developmental lesions. Activating mutations in the GNAS1 gene in a clone of osteoblastic cells, after clonal expansion, lead to the development of fibrous dysplasia. In this particular case, despite of the nonneoplastic behavior, a monoclonal pattern is observed (19). Therefore, clonality should be regarded as one but not the unique parameter for differentiation of a reactive lesion from a neoplastic process. The monoclonal pattern observed in CGCL indicates that these lesions may have a common genetic mechanism of development, which suggests that single forms of treatment may be effective. A recent study conducted by our research group showed that SH3BP2 gene pathway can be the underlying genetic alteration associated with CGCL pathogenesis (20).

Some samples of PGCL and CGCL showed a polyclonal pattern. This finding could be due nontumoral cells contamination, which may cause false impression of polyclonality. Also, a polyclonal early stage of the disease cannot be ruled out.

In conclusion, the findings of this study demonstrate that some giant cell lesions of the jaws are clonal. Further studies are necessary to better elucidate the molecular mechanisms involved in the pathogenesis of such lesions.

Table 1. Clinical data and results.

\begin{tabular}{ccccc}
\hline Diagnosis & Age (y) & Location & Aggressiveness & Clonality \\
\hline PGCL & & & & \\
1 & 8 & Maxilla & --- & Monoclonal \\
2 & 22 & Maxilla & --- & Monoclonal \\
3 & 15 & Mandible & --- & Polyclonal \\
4 & 50 & Maxilla & --- & Monoclonal \\
5 & 24 & Mandible & --- & Polyclonal \\
6 & 52 & Maxilla & --- & Polyclonal \\
CGCL & & & & \\
1 & 12 & Mandible & No & Monoclonal \\
2 & 41 & Mandible & No & Monoclonal \\
3 & 26 & Mandible & Yes & Polyclonal \\
4 & 25 & Mandible & Yes & Polyclonal \\
5 & 23 & Mandible & Yes & Monoclonal \\
\hline
\end{tabular}

$\mathrm{PGCL}=$ peripheral giant cell lesion; $\mathrm{CGCL}=$ central giant cell lesion. 


\section{RESUMO}

Apesar da importância que a clonalidade das lesões tem para o entendimento da patogênese e progressão dos tumores, ainda não foi feita essa investigação em lesões de células gigantes dos maxilares. O objetivo desse trabalho foi analisar a natureza clonal de lesões periféricas de células gigantes (LPCG) e de lesões centrais de células gigantes (LCCG). Foram analisadas nesse estudo 6 amostras de LPCG e 5 amostras de LCCG, sendo todas elas provenientes de pacientes do sexo feminino. Para essa investigação foi utilizado o método baseado na região polimórfica do exon um do gene humano para oreceptor de andrógeno (HUMARA). Três das 5 amostras de LCCG e 3 das 6 amostras de LPCG exibiram um padrão monoclonal. Nossos resultados demonstram que algumas lesões de células gigantes dos maxilares apresentam uma natureza monoclonal indicando que essas lesões podem ter um mecanismo genético comum de desenvolvimento. Outros estudos são necessários para uma maior compreensão dos mecanismos moleculares envolvidos na patogênese dessas lesões.

\section{ACKNOWLEDGEMENTS}

This study was supported in part by grants from The Minas Gerais State Research Foundation (FAPEMIG) and from Millennium/ National Council for Scientific and Technological Development (CNPq), Brazil. Dr. RS Gomez is research fellow of CNPq.

\section{REFERENCES}

1. de Lange J, van den Akker HP, van den Berg H. Central giant cell granuloma of the jaw: a review of the literature with emphasis on therapy options. Oral Surg Oral Med Oral Pathol Oral Radiol Endod 2007;104:603-615.

2. Horner K. Central giant cell granuloma of the jaws: a clinicoradiological study. Clin Radiol 1989;40:622-626.

3. Katsikeris N, Kakarantza-Angelopoulou E, Angelopoulos AP Peripheral giant cell granuloma. Clinicopathologic study of 224 new cases and review of 956 reported cases. Int J Oral Maxillofac Surg 1988;17:94-99.

4. Itonaga I, Hussein I, Kudo O, Sabokbar A, Watt-Smith S, Ferguson D, et al.. Cellular mechanisms of osteoclast formation and lacunar in giant cell granuloma of the jaw. J oral Pathol Med 2003;32:224 231.

5. Secker-Walker LM. The meaning of a clone. Cancer Genet Cytogenet 1985;16:187-188.

6. Nowell PC. The clonal evolution of tumor cell populations Science 1976;194:23-28.

7. Chen GL, Prchal JT. X-linked clonality testing: interpretation and limitations. Blood 2007;110:411-419.

8. Wainscoat JS, Fey MF. Assessment of clonality in human tumors: a review. Cancer Res 1990;50:1355-1360.

9. Holliday R. Ageing: X-chromosome reactivation. Nature 1987;327:661-662.

10 Riggs AD. X-inactivation, differentiation, and DNA methylation. Cytogenet Cell Genet 1975;14:9-25.

11. Fearon ER, Hamilton SR, Volgenstein B. Clonal analysis of human colorectal tumors. Science 1987;238:193-197.

12. Allen RC, Zoghbi HY, Moseley AB, Rosenblatt HM, Belmont JW. Methylation of HpaII and HhaI sites near the polymorphic CAG repeat in the human androgen-receptor gene correlates with $\mathrm{X}$ chromosome inactivation. Am J Hum Genet 1992;51:1229-1239.

13. Schwartz HS, Eskew JD, Butler MG. Clonality studies in giant cell tumor of bone. J Orthop Res 2002;20:387-330.

14. Boom R, Sol CJ, Salimans MM, Jansen CL, Wertheim-van Dillen $\mathrm{PM}$, van der Noordaa J. Rapid and simple method for purification of nucleic acids. J Clin Microbiol 1990;28:495-503.

15. Knudson AG Jr. Hereditary cancer, oncogenes, and antioncogenes. Cancer Res 1985;45:1437-1443

16. Leedham $\mathrm{S}$, Wright $\mathrm{N}$. Human tumour clonality assessment-flawed but necessary. J Pathol 2008;215:351-354

17. Garcia SB, Park HS, Novelli M, Wright NA. Field cancerization, clonality and epithelial stem cells: the spread of mutated clones in epithelial sheets. J Pathol 1999;187:61-81.

18. Alexander P. Do cancers arise from a single transformed cell or is monoclonality of tumours a late event in carcinogenesis? Br J Cancer 1985;51:453-457.

19. Gong L, Zhang W, Su Q. Clonal status of fibrous dysplasia. Pathology 2008;40:392-395.

20. Carvalho VM, Perdigão PF, Amaral FR, Souza PE, De Marco L, Gomez RS. Novel mutations in the SH3BP2 gene associated with sporadic central giant cell and cherubism. Oral Dis 2009;15:106110. 